Török Ádám

\title{
Vállalati és állami szerep a magyar iparfejlődésben a kilencvenes évek után
}

\begin{abstract}
A magyar ipar fejlődése a kilencvenes évtizedben először kiábránditó, utána pedig kifejezetten gyors és sikeres volt. Ezt az ipari átalakulási folyamatot számos közlemény' mutatta be általában, illetve a magyar ipar külpiaci teljesítményének tükrében. Az elemzések nagyobb része azonban mindenekelőtt statisztikai áttekintéseken alapult, és némileg elsikkadtak a folyamatok szereplői. Ebben a tanulmányban éppen ezért a fontosabb vállalati szereplők, illetve a kormányzat iparfejlődésre gyakorolt hatását, valamint viselkedését vizsgáljuk², és ebből következtetünk a 2003-2004 utáni magyar iparfejlődés stratégiai lehetőségeire. A tanulmány elöször a magyar ipar legfontosabb vállalati szereplőit tekinti át, majd külön kitér a külföldi iparvállalatok piaci jelenlétének sajátosságaira, arra, hogy az Európai Unió 2000 óta kirajzolódó versenyképesség-javitó ambíciói mennyiben tükröződhetnek a magyar gazdaságpolitikában. A kérdés tehát: lehet-e számítani az 1996 óta legalábbis tetszhalott magyar iparpolitika valamilyen mértékü újraéledésére, várható-e az európai normáknak megfelelő, mégis az ezredforduló körülinél jelentősen aktívabb állami szerep a magyar iparfejlődés ösztönzésében?
\end{abstract}

\section{A magyar ipar vállalati képének átalakulása}

Elöször azt próbáljuk szemügyre venni, hogy a vezető magyar iparvállalatok „térképe” mennyit változott a kilencvenes években. Ehhez a Figyelö címü folyóirat évenkénti jelentését hívjuk segítségül a magyar gazdaság legnagyobb vállalatairól ${ }^{3}$.

A 2002-ben közzétett vállalati listák közül az 50 legnagyobb export-árbevételű cég listáját választottuk ki (külön iparvállalati lista nem volt), mert a magyar ipar vezető cégei szempontjából ez a leginkább reprezentatív. Az 50 cég közül mindössze 7 (a 12. helyezett MALÉV Rt., a 25. helyen álló Wallis-csoport, a 30.-nak rangsorolt Opel Southeast Europe Kft., a 32. helyen álló Panrusgáz Rt., a 39. Porsche Hungária Kereskedelmi Kft., a 40. helyezett System Consulting Rt., valamint a 43.-nak rangsorolt Bábolna Rt.) nem iparvállalat.

Természetesen a lista több más szereplője csak részben iparvállalat, hiszen többé-kevésbé szolgáltató tevékenységet is végez. A modern iparban azonban a tisztán termelési jellegü profil már igen-igen ritka, és tartalmi megítélése sem mindig egyszerü. A listán ugyancsak szereplö Videoton Holding Rt. például telephelyet ad bérbe és munkaeröt kölcsönöz Magyarországon befektető iparvállalatoknak: igen nehéz eldönteni tehát, hogy önmaga mennyiben végez kimondottan ipari jellegű tevékenységet.

${ }^{1}$ különösen: KSH 1991-től 2003-ig; KSH 2002a; Török, 1997 Köves, 2003a,b

"E témát sokáig nem tekintették „szalonképesnek".

${ }^{3}$ Az alábbi adatok forrása: Top-200. Sanoma Budapest Lapkiadó Rt., 2002. október.

Török Ádám az MTA levelező tagja, a Veszprémi Egyetem és a BME egyetemi tanára, az Acta Oeconomica főszerkesztője. E-mail: torokadam@yahoo.com 
A magyar ipar nagy exportőr vállalatai 2001-ben, „régi”, ,átalakult” és „új” piaci szereplök

\begin{tabular}{|c|c|c|c|c|c|}
\hline Hagyományos cégek & $\begin{array}{c}\text { He- } \\
\text { lyezés }\end{array}$ & Átalakult cégek & $\begin{array}{c}\text { He- } \\
\text { lyezés }\end{array}$ & Új piaci szereplők & $\begin{array}{l}\text { He- } \\
\text { lyezés }\end{array}$ \\
\hline Alcoa KÖFÉM Kft & 11 & $\begin{array}{l}\text { MOL Magyar Olaj- } \\
\text { és Gázipari Rt. }\end{array}$ & 6 & $\begin{array}{l}\text { Audi Hungária } \\
\text { Motor Kft }\end{array}$ & 1 \\
\hline $\begin{array}{l}\text { Tiszai Vegyi Kombinát } \\
\text { Rt }\end{array}$ & 13 & Videoton Holding Rt & 22 & $\begin{array}{l}\text { IBM Storage } \\
\text { Products Kft } \\
\end{array}$ & 2 \\
\hline $\begin{array}{l}\text { Electrolux Lehel } \\
\text { Hütőgépgyár Kft }\end{array}$ & 14 & $\begin{array}{l}\text { Rába Jármüipari } \\
\text { Holding Rt }\end{array}$ & 24 & $\begin{array}{l}\text { Philips } \\
\text { Magyarország }\end{array}$ & 3 \\
\hline $\begin{array}{l}\text { Richter Gedeon } \\
\text { Vegyészeti Gyár Rt }\end{array}$ & 15 & $\begin{array}{l}\text { MAL Magyar } \\
\text { Alumínium Termelő } \\
\text { és Szolgáltató Rt }\end{array}$ & 26 & $\begin{array}{l}\text { Flextronics } \\
\text { International Kft }\end{array}$ & 4 \\
\hline Dunaferr-csoport & 16 & $\begin{array}{l}\text { Robert Bosch } \\
\text { Elektronika Gyártó } \\
\mathrm{Kft}\end{array}$ & 31 & Nokia Komárom Kft & 5 \\
\hline Borsodchem Rt & 17 & $\begin{array}{l}\text { BPW-Rába } \\
\text { Futómügyár Kft }\end{array}$ & 33 & $\begin{array}{l}\text { Opel Magyarország } \\
\text { Autóipari Kft }\end{array}$ & 7 \\
\hline $\begin{array}{l}\text { Chinoin Gyógyszer és } \\
\text { Vegyészeti Termékek } \\
\text { Gyára Kft }\end{array}$ & 21 & $\begin{array}{l}\text { Alcoa Európai } \\
\text { Keréktermék Gyártó } \\
\text { Kft }\end{array}$ & 36 & $\begin{array}{l}\text { NABI Észak- } \\
\text { Amerikai Járműipari } \\
\text { Rt }\end{array}$ & 8 \\
\hline $\begin{array}{l}\text { Magyar Villamos } \\
\text { Müvek Rt }\end{array}$ & 23 & \begin{tabular}{|l} 
Luk Savaria \\
Kuplunggyártó Kft \\
\end{tabular} & 37 & Suzuki Rt & 9 \\
\hline $\begin{array}{l}\text { Pick Szeged } \\
\text { Szalámigyár és } \\
\text { Húsüzem Rt }\end{array}$ & 27 & $\begin{array}{l}\text { Michelin Hungária } \\
\text { Abroncsgyártó Kft }\end{array}$ & 38 & $\begin{array}{l}\text { Samsung Electronics } \\
\text { Magyar Rt }\end{array}$ & 10 \\
\hline Egis Gyógyszergyár Rt & 29 & Nestlé Hungária Kft & 42 & Visteon Hungary Kft & 18 \\
\hline Henkel Hungária Kft & 41 & \begin{tabular}{|l} 
Unilever \\
Magyarország Kft
\end{tabular} & 44 & $\begin{array}{l}\text { Delphi Packard } \\
\text { Hungary Kft }\end{array}$ & 19 \\
\hline $\begin{array}{l}\text { MKM Magyar Kábel } \\
\text { Művek Rt }\end{array}$ & 46 & $\begin{array}{l}\text { Ikarusbus } \\
\text { Jármügyártó Rt }\end{array}$ & 45 & $\begin{array}{l}\text { Sony Hungária } \\
\text { Értékesító és } \\
\text { Szolgáltató Kft }\end{array}$ & 20 \\
\hline $\begin{array}{l}\text { Dunapack Papír és } \\
\text { Csomagolóanyag Rt }\end{array}$ & 47 & Taurus Gumiipari Rt & 48 & Sanyo Hungary Kft & 28 \\
\hline \multirow[t]{3}{*}{ Csepeli Fémmü Rt } & 50 & & & TEMIC Hungary Kft & 34 \\
\hline & & & & $\begin{array}{l}\text { ZF Hungária Ipari és } \\
\text { Kereskedelmi Kft }\end{array}$ & 35 \\
\hline & & & & $\begin{array}{l}\text { LG Electronics } \\
\text { Magyar Kft }\end{array}$ & 49 \\
\hline
\end{tabular}

Forrás: Vállalatnevek és rangsor: Figyelő TOP-200 2002. Sanoma Holding Rt., 2002 október. 40. A besorolást a szerző készítette. 
A fennmaradó 43 céget három csoportra osztottuk, amit az 1. táblázat szemléltet. A első csoportba soroltuk azokat a cégeket, amelyek 1990 óta változatlan vagy nagyjából változatlan formában és tevékenységi körrel - természetesen nem feltétlenül az akkori tulajdonos ellenőrzése alatt - vannak jelen a magyar iparban. A második csoportba kerültek azok a vállalatok, amelyek eredeti nevüket megtartották ugyan, de profiljukban, méretükben és határaikban közben már jelentős változások történtek. A harmadik csoportot pedig a magyar ipar teljes mértékben új piaci szereplői alkotják.

A három oszlop szinte pontosan egyforma hosszú (14, 13 és 16 céget tartalmaznak), belső struktúrájuk azonban nagyban eltér. A kiemelkedő exportőrök - közöttük az azóta megszünt IBM Storage Products Kft - a piac új szereplöi közé tartoznak, a vezető exportőrök listájáról az első 20 cég közül 12 itt található. A középmezőnyt inkább a „hagyományos" piaci szereplők alkotják, az átalakult piaci szereplők jelentős része pedig a rangsor második felébe került. Jellemzi ezt, hogy az első oszlop helyezési számainak átlaga 26.4, a második csoportban a megfelelő mutató 33.2, a harmadik oszlopban pedig kifejezetten alacsony, csupán 15.8 .

A három oszlopban szereplő vállalatok iparági megoszlása jó magyarázatot adhat arra a súlyeltolódásra, amely szerint a vezető ipari exportőrök többnyire a magyar ipar új piaci szereplöi. A harmadik oszlop minden cége gépipari vállalat, és a 16 vállalat közül 8 a jármüiparban müködik, a másik 8 pedig az elektronikai iparban. Ezzel szemben az első csoportban mindössze 2 a gépipari vállalat ${ }^{4}$, ott viszont 6 vegyipari és 3 kohászati vállalkozás található.

$\mathrm{Az}$,átalakult” piaci szereplők csoportjában különösen vegyes a kép. Ott a felsoroltak csaknem fele, 6 cég ugyancsak a gépiparhoz tartozik. Ebben az oszlopban a sokszínü iparági megoszlás mellett viszont fellelhető a magyar ipar több korábbi sikeres exportőrének (Ikarus, RÁBA, Videoton, Taurus, Rákospalotai Növényolajipari Vállalat) a „leszármazottja”. Ebből az látható, hogy a magyar ipar sok korábbi, részben keleti irányban exportorientált nagyvállalatának voltak olyan elemei, amelyek megtartásával új tulajdonos kezében a piacon maradhattak. Itt azonban sem csúcstechnológiai exportőrökről, sem a magyar ipari kivitel „hordozó” cégeiről nincs szó, sokkal inkább korábbi struktúrák esetenként kifejezetten nehézkes továbbéléséröl. A felsorolt 6 cég közül az Ikarusbus és a Rába Holding válsága 2003-ban széles körben ismertté vált tény, a Videoton Holding pedig 2001 óta ugyancsak jelentős elbocsátásokra kényszerült ${ }^{5}$.

Âltalában a középső oszlop vállalatai voltak a 2000-es évek elején a leginkább ingatag helyzetben a 2001-es vezető ipari exportörök közül. Érdekes, hogy a stabilabb helyzetü cégekből álló első oszlop vállalatai jelentős részben olyanok, amelyek 1990 előtt aránylag versenyképes „,keményvalutás” exportőrök voltak (különösen a gyógyszeripari és a kohászati vállalatok), tehát piaci pozícióik megtartásához az új tulajdonosoknak nem kellett mélyebb vállalati szerkezeti változásokat végrehajtaniuk. A harmadik oszlop pedig nagyrészt olyan, „zöldmezős” beruházással létrejött cégekbőláll, amelyek eleve exportorientált céllal jöttek létre.

${ }^{4}$ A GE - Tungsram céget az első oszlopba kellett volna sorolnunk, de a forrás nem tüntette fel a vezető exportőrök között, mert nem szolgáltatott ilyen adatot.

5 2001-ben a Videoton Holding létszáma mintegy 5, a Rába Holdingé pedig 11 százalékkal csökkent (Figyelő TOP 200, 2002:32). 
Ezek a cégek részben a magyar gazdaság legjelentősebb exportőreivé váltak. Többségüknél a Magyarországon létrehozott kapacitások erősen tőkeintenzív jellege miatt nem is kell tartani attól, hogy kisebb konjunkturális megrázkódtatások vagy a költségterheik növekedése miatt kivonulnak az országból.

A szakirodalom „, footloose”(„nem beágyazódott”) kapacitásoknak nevezi azokat, amelyek nem kötödnek szorosan a befogadó ország gazdaságához, s gyorsan továbbállnak, ha más telephelyeken alacsonyabb költségekre vagy jobb piaci lehetőségekre számítanak. Ilyen eseteket föleg a könnyüiparban találhatunk, amely munkaerö-igényes termelést folytat, a gépek könnyen felállíthatók és leszerelhetők.

A magyar könnyüiparban a nyolcvanas évek elejétől nyugati partnerekkel kialakult bérmunka-konstrukciók kedvező foglalkoztatásilehetőségeket teremtettek, éshosszúidőrebiztosítottákakapacitásokfennmaradását.Számosbérmunka-megállapodásbólkésőbb vegyesvállalatok is kialakultak. A forint felértékelődése, a magyar munkaerő megdrágulása, nem utolsósorban a kevésbé fejlett környező országok (Románia, Bulgária, Ukrajna) világgazdasági nyitása, valamint az igen alacsony kínai termelési költségek miatt azonban a kilencvenes évek végén megindult a magyarországi „footloose” kapacitások Kelet felé települése. Ezt különösen a magyar ruházati és a cipőipar, kisebb mértékben az élelmiszeripar sínylette meg. Ez a folyamat törvényszerü következménye volt annak a ténynek, hogy Magyarország már nem számít olcsó ipari telephelynek, és versenyképességi elönyeit mindinkább munkaereje felkészültségében és innovativitásában kell keresnie.

A kapacitások „footloose” jellege azonban nem szigorúan iparág-specifikus jelenség. Ott is tapasztalható, ahol látszólag magas technológiai szintű termelés folyik, de az igen korszerü berendezéseket nagyrészt betanított munkások üzemeltetik, és a gyártás csakis importált alkatrészek összeszereléséből áll. Ezek a korszerü üzemek gyorsan leállíthatók, és berendezéseik visszaszállítása külföldre sem igényel sok időt.

Jellegzetes példája volt az ilyen jellegü ,footloose” termelésnek az IBM székesfehérvári merevlemez-gyára, amelyet 2002-ben bezártak. Ez a gyár 2001-ben még a magyar export mintegy 8 százalékát adta ${ }^{6}$. Bezárásának valószínűleg nem volt köze az ipar külföldre településekor gyakran emlegetett költség-szempontokhoz. Az IBM eladta a székesfehérvári üzemet is magában foglaló divízióját egy japán nagyvállalatnak, amely ezekből a termékekből a világon fölösleges kapacitásokkal rendelkezett. Így az üzemet valójában már nem az IBM zárta be.

Az IBM esetét nem szabad általánosítani, mert a magyar iparban a nyolcvanas évek közepétől a 2000-es évek elejéig megtelepedett külföldi tulajdonú vállalatok nagy része tartósan az országban maradt. Technológiákat, piaci kapcsolatokat, vállalatirányítási ismereteket hozott, munkahelyeket teremtett s így a magyar gazdaságfejlődésre feltétlenül kedvező hatása volt.

A következőkben azt tekintjük át, hogy a 2001-es évre vonatkozó adatok szerint a magyar iparban milyen valóban jelentős, külföldi többségi tulajdonú nagyvállalatok működtek, és gazdaságfejlődési hatásaikat is megpróbáljuk összefoglalni. Csak azokkal az iparvállalatokkal foglalkozunk, amelyek szakmai befektetők tulajdonában vannak, így van olyan anyavállalatuk, amelyhez fejlődési stratégiájuk köthető, illetve amelynek a globális stratégiájában jól kitapintható funkció jutott nekik. 
A magyar ipar vezető külföldi többségi tulajdonú exportőr cégei

2. táblázat

\begin{tabular}{|c|c|c|c|c|c|}
\hline Cég & Anyacég & Anyaország & Iparág & $\begin{array}{c}\text { Export } \\
\text { (mó } \\
\text { USD) }\end{array}$ & $\begin{array}{c}\text { Export/ } \\
\text { magyar } \\
\text { összexport } \\
(\%)\end{array}$ \\
\hline $\begin{array}{l}\text { Audi Hungária } \\
\text { Motor Kft }\end{array}$ & Volkswagen & Németo. & Autó & 3187 & 11.2 \\
\hline $\begin{array}{l}\text { IBM Storage } \\
\text { Products Kft }\end{array}$ & IBM & USA & Elektronika & 2240 & 7.8 \\
\hline $\begin{array}{l}\text { Philips } \\
\text { Magyarország }\end{array}$ & Philips & Hollandia & Elektronika & 2027 & 7.1 \\
\hline GE Hungary Rt & $\begin{array}{l}\text { General } \\
\text { Electric }\end{array}$ & USA & $\begin{array}{l}\text { Fényforrás- } \\
\text { gyártás }\end{array}$ & 639 & 2.2 \\
\hline $\begin{array}{l}\text { Opel Magyarország } \\
\text { Jármügyártó Kft }\end{array}$ & $\begin{array}{l}\text { General } \\
\text { Motors }\end{array}$ & USA & Autó & 628 & 2.2 \\
\hline $\begin{array}{l}\text { Flextronics } \\
\text { International } \mathrm{Kft}\end{array}$ & Flextronics & Szingapur & Elektronika & 430 & 1.5 \\
\hline Alcoa Köfém Kft & Alcoa & USA & Alumínium & 314 & 1.1 \\
\hline Suzuki Rt. & $\begin{array}{l}\text { Suzuki } \\
\text { Motor }\end{array}$ & Japán & Autó & 300 & 1.1 \\
\hline NABI Rt. & $\begin{array}{l}\text { North } \\
\text { American } \\
\text { Bus } \\
\text { Industries }\end{array}$ & USA & Autó & 249 & 0.9 \\
\hline $\begin{array}{l}\text { Samsung Electronics } \\
\text { Magyar Rt. }\end{array}$ & $\begin{array}{l}\text { Samsung } \\
\text { Electronics }\end{array}$ & Dél-Korea & Elektronika & 241 & 0.8 \\
\hline $\begin{array}{l}\text { Electrolux Lehel } \\
\text { Hütőgépgyár Kft }\end{array}$ & Electrolux & Svédország & $\begin{array}{l}\text { Háztartási } \\
\text { gépgyártás }\end{array}$ & 212 & 0.7 \\
\hline $\begin{array}{l}\text { Visteon Hungary } \\
\mathrm{Kft}\end{array}$ & Visteon & USA & $\begin{array}{l}\text { Elektronika/ } \\
\text { autó }\end{array}$ & 187 & 0.7 \\
\hline $\begin{array}{l}\text { Delphi Packard } \\
\text { Hungary Kft }\end{array}$ & $\begin{array}{l}\text { Delphi } \\
\text { Automotive } \\
\text { Systems }\end{array}$ & USA & Autó & 169 & 0.6 \\
\hline $\begin{array}{l}\text { Egis Gyógyszergyár } \\
\text { Rt }\end{array}$ & Servier & Franciao. & Gyógyszer & 102 & 0.4 \\
\hline
\end{tabular}

Forrás: UNCTAD, 2002. 171., a szerző saját korrekcióival 


\section{Külföldi tulajdonú nagyvállalatok a magyar iparban}

A magyar iparban működő külföldi tulajdonú nagyvállalatok döntő többsége exportőr cég, ami a magyar piac kis mérete és nyitottsága miatt teljes mértékben érthető. A 2001. évre vonatkozó statisztikai forrásunk ${ }^{7} 50$ céget sorol fel, de ezt a listát az alábbi táblázatban jelentősen szűkítettük. Csak a magyar exportban legalább 0.4 százalékos részesedést elért cégeket soroljuk fel, és kihagytuk a kifejezetten kereskedelmi jellegü vállalkozásokat. Így az 5. táblázat listáján végül 14 céget tüntettünk fel. Ezek együtt 2001-ben a magyar összexport 38.3 százalékát, a külföldi tulajdonú vállalkozásoktól eredő exportnak pedig csaknem l-ét produkálták, így reprezentatív mintáról van szó.

A lista több szempontból is meglepően koncentráltnak mutatkozik, mégpedig elsősorban a tulajdonosok országa és az iparágak szerint.

Igaz, a tulajdonos cég országának a multinacionális vállalatok korában nincs igazi jelentősége. Különösen akkor nincs, ha a cég részvényeinek többségét a tőzsdén jegyzik, illetve, ha a végső tulajdonos (tehát például az Opel Hungary esetében nem a németországi anyavállalat, hanem a General Motors) székhelye a leányvállalat ügyeiben nem a valódi döntési központ. A nemcsaknemzetközileg decentralizált, hanem földrajzilagkifejezetten szétszórt vállalatcsoportok jó példája a Flextronics, amelyet valóban egy szingapúri bejegyzésű holding ellenőriz, a tényleges vállalati központ azonban Londonban van. A cég nem saját neve alatt gyártja termékeit, hanem nagy elektronikai cégek gyártmányainak sokszor teljes sorozatú előállítását vállalja a bérmunka sajátos válfajaként.

Mégis érdekes látni azt, hogy a magyar feldolgozó iparban valóban fontos szerepet játszanak a végső soron amerikai tulajdonú nagyvállalatok - amelyek sorából azonban az IBM 2002-ben kiesett a komolyabb magyarországi jelenlét szempontjából -, közöttük a világgazdaság kiemelkedően fontos szereplöi. A felsorolt cégek pontosan fele amerikai hátterü, a többiek közül pedig 1-1 a német, a holland, a svéd, a szingapuri, a japán, a francia és a dél-koreai ${ }^{8}$.

$\mathrm{Az}$ amerikai hátterű magyarországi nagyvállalatok technológiai kapcsolataik szempontjából két markáns csoportra oszthatók. Az egyik csoportba sorolhatjuk az olyanokat, mint az Opel, az Alcoa vagy a GE Hungary, amelyek kifejezetten a vállalatcsoport európai munkamegosztási rendszerében jutnak szerephez (tehát az európai érdekeltségek beszállítói, illetve európai döntési központok által irányított vállalati hálózatok tagjai). Mások pedig - a Delphi, a Visteon vagy az IBM - a válla latcsoport globális beszállítói rendszerébe tagozódtak. Külön esetnek tekinthetjük az amerikai mércével kis méretű s multinacionális vállalatnak semmiképpen sem beillő NABI-t, amely kisebb sorozatokban Magyarországon szerel össze városi autóbuszokat az amerikai piac számára.

A földrajzi koncentráció fokát tehát csak meglehetős óvatossággal becsülhetjük meg a magyar feldolgozó ipar jelentős külföldi szereplöi esetében, az iparági koncentráció azonban jóval világosabban megmutatkozik. A 14 cégből - ismét beleszámítva a magyar gazdaságban több mint 6 évig jelen volt IBM-et - a többség két iparágat képvisel: a Visteonnal együtt az autóipart, 6 pedig az elektronikai és villamosgép-gyártó ipart (beleértve a fény-

${ }^{7}$ UNCTAD 2002:171. Az ott megjelölt források: a Figyelő 2001-es TOP 200-as listája, valamint a „Who Owns Whom" CD-ROM (Dun and Bradstreet).

${ }^{8} \mathrm{~A}$ vállalatnevekböl nem is mindig látszik a tényleges tulajdonosi háttér, a Visteon például a Ford-csoport tagja. 
források és a háztartási gépek gyártását). A másik 2 nagy cég a gyógyszeriparban és a színesfémkohászatban müködik.

A magyar ipart tehát a kilencvenes években különösen két iparág, a gépkocsiipar és az elektronikai ipar multinacionális vállalati befektetői tekintették stratégiai befektetési célpontnak. Mindkét iparág esetében a magyar ipari hagyományok és a kedvező munkaerő-költségek mellett a telephelyi adottságok és a jelentős állami befektetési támogatások növelték meg a magyarországi beruházások vonzerejét a multinacionális vállalatok szemében.

Az autóiparban a külföldi befektetések hulláma 1990-ben kezdődött, amikor az import liberalizálása lehetővé tette a magyar lakosság évtizedek alatt felhalmozott gépkocsikeresletének gyors kielégítését. A személygépkocsi-import legkedvezőbb vámszintje is - a kapcsolódó adókat beleszámítva - körülbelül 20 százalékos volt a kilencvenes évtized első felében, ezért több külföldi személygépkocsi-ipari cég magyarországi autógyár felépítését fontolgatta?.

Az 1990-1991-es év három nagy külföldi autóipari beruházása közül kettő, a szentgotthárdi Opel- és az esztergomi Suzuki-gyár kezdetben egyaránt a magyar piaci igények kielégítését szolgálta Nyugaton már bevált olcsó és megbízható, a kis- és az alsó-középkategóriába tartozó típusokkal. A két gyár a vámterhek hiánya és a magyar kormány által nyújtott évtizedes nyereségadó-mentesség miatt több mint 20 százalékos költségelönyt élvezett, de ezt az elönyt csökkentette az Opel esetében az Astra típus drága kézi összeszerelése, a Suzukinál pedig az, hogy a föegységeket Japánból kellett importálni. Mégis, 1992-ben már a magyarországi személyautó-értékesítés összesen több mint 40 százalékát a két külföldi tulajdonú személygépkocsi-összeszerelő üzem szolgáltatta.

A két autógyár később eltérő stratégiai irányban fejlődött. Az Európa-megállapodás nyomán az uniós országokból származó autóimport vámjai 1997-re megszüntek. Így a magyarországi Opel-gyártás is befejeződött, és az üzem azóta sebességváltó- és motorgyárként működik. A Suzuki viszont legfontosabb európai hídfőállását építette ki Esztergomban. Termelésének nagyobb hányada a kilencvenes évek vége óta exportra kerül, és a cég kisautó-modelljeinek (Swift, Wagon R+, majd 2003-tól az Ignis) európai keresletét már ez a gyár elégíti ki.

A harmadik nagy magyarországi autóipari beruházást a Ford hajtotta végre Székesfehérváron a kilencvenes évek legelején. Ez az üzem kezdettől fogva a multinacionális nagyvállalat nemzetközi logisztikai rendszerébe illeszkedett, európai, dél- és észak-amerikai gyárainak egyaránt az alkatrész-beszállítója volt. A magyarországi Ford-gyár azonban sohasem szerelt össze autókat. A cég úgy próbálta megkerülni a magyarországi piacrajutás kereskedelmi akadályait, hogy a magyar kormánnyal - egy bizonyos kisáruszállító-típusára, azt nem megnevezve, de nagyon pontosan specifikálva - vámmentességben állapodott meg $^{10}$.

${ }^{9}$ A KGST-együttmüködés örökségeként egy ideig kelet-európai típusok magyarországi gyártására is készültek, de ezek a kevés tőkére és részben nem megfelelően korszerü magyar ipari kapacitásokra épített tervek hamar megbuktak azért, mert a hazai vásárlóközönség már csak nyugati típusok iránt érdeklődött

${ }^{10}$ A müködőtőke-importnak ez a nem transzparens ösztönzője azonban a konkurencia igen heves tiltakozását váltotta ki. Ezért a kormánynak 1992-ben az összes hasonló kisáruszállitó jármüre ki kellett terjesztenie a vámmentességet, a Fordot pedig telekjuttatással kárpótolta veszteségéért. A Ford később átszervezte beszállitói hálózatát, így a székesfehérvári üzem a Visteon-csoport része lett a korábbival megegyező termelési profil mellett. 
Az Opel, a Suzuki és a Ford, később pedig a Delphi egyaránt hasonló stratégia alapján, a piacszerzést és az olcsó beszállítói kapacitás kiépítését szem előtt tartva létesített autóipari üzemet Magyarországon. Ez a befektetői stratégia elsősorban a fejlődő és a kevésbé iparosodott európai országok autóiparában gyakori. Általában nem jelenti a legfejlettebb technológiák külföldre telepítését, és a hasonló beszállító vagy összeszerelő jellegű telephelyek nem is vesznek részt a vállalatcsoport kutatás-fejlesztési tevékenységében. A négy cég közül csak a Suzuki törekedett arra, hogy hosszabb időre magyar beszállítói hálózatot is kiépítsen magának. A magyar alkatrészek legalább 60 százalékos költséghányada volt ugyanis a feltétele annak, hogy a Magyarországon gyártott Suzukik a magyar termékeket megillető vámkedvezményekkel kerülhessenek az Európai Unió piacára.

Ezért volt nagy horderejű fejlemény, amikor az Audi 1993-ban Győr városát választotta ki - a korabeli hírek szerint spanyol, keletnémet és cseh telephelyekkel szemben - új motorgyárának telephelyéül. Ez a gyár a cég, sőt az egész Volkswagen-csoport akkor bevezetésre kerülö 5 szelepes motorcsaládjának a gyártóbázisává vált, amely igen szoros integrációban müködik az Audi központi, ingolstadti üzemével. 1999-ben a magyar kormány támogatásával itt épült fel a vállalatcsoport motorfejlesztő központja is. Ez volt az első eset a magyar autóiparban, amikor egy jelentős külföldi beruházás nemcsak a magyarországi telephely könnyű elérhetősége és a viszonylag alacsony magyar munkaerő-költségek miatt valósult meg, hanem alapvetô szempontja volt a magyarországi szellemi tőke minősége is. Nem sokkal később hasonló fejlesztőközpontot hozott létre a Knorr-Bremse, Európa vezető fékberendezés-gyártója ugyancsak magyar állami támogatással Budapesten.

A magyar elektronikai iparban vegyes a kép. A felsorolt - nagy exportkapacitású multinacionális vállalati telephelyek közül csak a GE-Tungsram kapott kimondott stratégiai irányítási és fejlesztési funkciót a cégcsoport európai működésében, bár az Electrolux is magyar cégénél végzi egyes fejlesztési tevékenységeit. A Philips, a Samsung vagy a Flextronics, különösen pedig az IBM azonban kifejezetten a magyarországi telephely kedvező költségei, különösen a bérköltség-alapú versenyképességi elönyök miatt alakította ki exportbázisát az országban.

A külkereskedelmi statisztikák bizonyítják, hogy a Philips videomagnóinak az egykori hollandiai, majd a magas bérköltségek miatt Ausztriába vándorolt gyártókapacitása azért jött tovább Magyarországra, hogy a továbbiakban ez az egyelöre olcsó telephely lássa el a vállalatcsoport nyugat-európai piacait jó minőségű, ám nem kiemelkedően korszerű Philips-termékekkel. Feltételezhető, hogy a fogyasztói elektronikai ipar kapacitásainak keletre településének folyamata nem áll meg a magyar határoknál, és 2005-2008 között a Philips gyártókapacitásai is Románia, Ukrajna, esetleg Kína felé veszik az útjukat Magyarországról.

A magyar elektronikai iparban a Nokia egyelőre kisebb exportkapacitású s így a táblázatban nem szereplő komáromi telephelye hasonló jellegü, mint amit az Audival vagy a Knorr-Bremsével kapcsolatban láttunk. Komáromban is regionális fejlesztőközpont alakult ki, amely ugyancsak a magyar szellemi tőke jó minősége, s nem az átmenetileg alacsony munkaerő-költségek miatt települt az országba.

A magyar működőtőke-import iparfejlesztési hatásai összességükben feltétlenül kedvezőnek minősíthetők. A magyar ipar új kapacitásaitól azonban nem minden esetben várható tartós jelenlét, illetve gazdaságösztönző hatás, amint ezt a székesfehérvári IBM-üzem bezárásának példája már jelezte is. Több nagy, a külföldi működő tőke által létrehozott feldolgozó ipari beruházás csak az alacsony munkaerő-költségek és egyéb átmeneti te- 
lephelyi előnyök miatt jött létre, de kevés a nagyobb arányú magyar beszállításokat felhasználó, illetve a magyar kutató-fejlesztő erőforrásokra alapozó multinacionális vállalati telephely Magyarországon.

Ez a tény a multinacionális vállalatokra alapozott exportstruktúra bizonyos fokú sérülékenységét jelenti, és elengedhetetlenné teszi azt, hogy a kormányzat a működőtőke importjának újabb ösztönzőit építse be a magyar ipar fejlesztési hajtóerői közé. Ehhez viszont határozott iparpolitikai stratégia volna szükséges.

\section{A magyar iparpolitika visszavonulása}

A magyar gazdaság átalakításában fontos alkotóelem volt az állam gazdasági szerepének számottevő visszaszorítása. Az iparban ennek eszköze részben a privatizáció volt, de az iparfejlődés állami orientálása és a struktúrapolitika is nagyban veszített erejéből. Noha a kilencvenes években hasonló folyamatok játszódtak le egész Európában, 2000 után az újabban versenyképesség-javító gazdaságpolitikaként jelölt iparpolitika bizonyos visszatérése tapasztalható az Európai Unió globális versenyképességi lemaradása miatt.

A magyar iparpolitika periódusai tükrözik az ipar szervezeti és tulajdoni átalakulásának előrehaladását, ugyanakkor gyakran látható bennük a kormányzat bizonytalansága is a még szükséges állami szerepvállalás mértékét illetően. Az 1990 utáni időszakot iparpolitikai szempontból négy részre osztjuk:

- a „piacorientált” szakasz (1990-1991), amikor a magyar kormány úgy vélte, hogy a magyar iparban szükséges szerkezetátalakítást a piaci erők hatására lehet bízni ${ }^{11}$;

- a „konszolidációs” szakasz (1991-1996), amikor a magyar iparpolitika tudatosan vállalkozott az ipar tartós válsággócainak egyenkénti kezelésére a további kiegyensúlyozott fejlődés érdekében;

- a „stratégiai” szakasz (1995-1997), amikor a magyar iparfejlődés szükséges irányait középtávú forgatókönyvek alapján próbálták kialakítani;

- a „passzív” szakasz (1998- ), amikor a magyar iparpolitika intézményi hátterét is leépítették abban a hitben, hogy a magyar ipar gyors növekedéséhez és versenyképesség-javulásához hosszabb távra létrejöttek a feltételek.

Az utóbbi feltételezés azonban nem igazolódott be. A magyar gazdaságpolitikának az ország EU-belépésének időszakában az iparcikk-export versenyképességének romlásával kell szembenéznie. E folyamat megfordítását nagyban segítheti a megfelelő monetáris-fiskális politikai keverék kialakítása, és a relatív munkaerőköltségek csökkentése. Nem biztos azonban, hogy mindez elegendő lesz. 2003-ban már Brüsszelben sem tartották elégségesnek a versenyképesség-javitó politika szektor-semleges eszközeit. Alapkérdés az Európai Bizottság és a magyar kormányzat számára is, hogy van-e, lehet-e még olyan iparpolitikai eszköztár a gazdaságpolitika kezében, amely az ipari folyamatok megfelelő mederbe terelését segítheti elő a korábbi versenyképesség visszaszerzése érdekében.

Aktív magyar iparpolitikát nemcsak hazai közgazdászok, kutatók, illetve kormányzati szakemberekjavasolnak. A Magyar EU Bővítési Üzleti Tanács 2003-as ajánlásaiban hang-

"Pedig már akkor is ismert volt a finn felzárkózási stratégia példája, amelyben jelentös volt az állami szerep (Török 2001a,b). 
súlyozza, hogy „... A nemzetközi technológia magyarországi elterjedésének meghatározó katalizátora lehet egy professzionális iparpolitika" (HEBC, 2003. 45.). Ez két igen fontos, az utóbbi években még magyar szakértőktől sem hallott következtetést alapoz meg: 1. a külföldi befektetők egyáltalán nem iparpolitika-ellenesek, azaz nem vetik el a kormányzat aktív szerepét az ipari folyamatok alakításában; 2. a jelenlegi magyar „iparpolitikát” finoman szólva is elégtelennek tartják úgy a magyar gazdaság növekedési és versenyképességi lehetőségei, mint a saját üzleti érdekeik szempontjából. A befektetőbarát magyar gazdaságpolitikának tehát minél hamarabb meg kell teremteni az iparpolitikai komponensét is.

\section{A magyar iparpolitika nemzetközi feltételei}

Az EU-szintű iparpolitika hiányának a fö jogi oka az, hogy a Római Szerződés nem definiálta az iparpolitika önálló kereteit. Meghatározta számos részpolitika (így például a mezőgazdasági, a kereskedelem-, a verseny- vagy a regionális politika) közös intézményés szabályrendszerét, de nem teremtett közös iparpolitikát.

Az integráció első két évtizedében csak egy szűkebb szektorban, a szén- és acéliparban létezett a közösségi cselekvés lehetősége. Az Európai Szén- és Acélközösség (Montánunió) azonban már 1951-ben létrejött a későbbi Európai Közösségek elődszervezeteként, a Római Szerződés életbe lépése után pedig a jelenlegi integráció magvát alkotó Európai Közös Piac mellé rendelten, attól formálisan függetlenül működött. A Montánunió azonban nem valamilyen közös szénbányászati vagy kohászati stratégiához nyújtott keretet, hanem inkább termelés-összehangoló és piacszabályozó szervezet volt 50 évre tervezett fennállása alatt.

Egyes európai iparágak válsága a hetvenes évektől szükségessé tette, hogy a Közösség az iparpolitikai keretek hiánya ellenére is, a fennálló szabályozási rendszerek felhasználásával ágazati szerkezet-átalakító programokat indítson. Ilyen volt az acéliparban a sikeresnek bizonyult Davignon-terv, később pedig a hajóipari válságkezelő program. Sem ez nem jelentett azonban konzisztens közösségi iparpolitikai cselekvést, sem az, amikor a nyolcvanas évek közepén a brit és a spanyol autóiparban Brüsszel megakadályozta a túlzott állami részvételt a British Leyland, illetve a SEAT konszolidációjában és privatizációra való előkészítésében.

A távol-keleti országok iparpolitikai buzgóságával ellentétes nyugat-európai iparfejlödési modell azonban 1973 után kérdésessé vált. Az egyre magasabb költségekkel termelő német, francia, brit és olasz ipar világpiaci térvesztése az olajválság után hosszabb távú, csak egyes időszakokban lelassuló folyamatnak bizonyult. Ezért az integrációt megújító maastrichti szerződés 1992-ben bevezette azt, amit a szakirodalom „implicit iparpolitikának" keresztelt el - ez a gyakorlatban más részpolitikák (így a versenypolitika) nem deklaráltan iparpolitikai célú alkalmazását is jelentette ${ }^{12}$. A szerződés tartalmazza a megengedett versenyképesség-javító eszközök listáját, de továbbra sem él az „,iparpolitika” kifejezéssel.

Az európai integráció kilencvenes évekbeli ipari fejlődése azonban nem váltotta be a reményeket, a versenyképességi lemaradás tovább nőtt elsősorban az észak-amerikai or-

${ }^{12}$ Ennek részletes elemzését lásd: (Török 1999). 
szágokkal és Japánnal szemben. A világ iparcikk-exportjában az EU részesedése 19.2-ről 18.4 százalékra csökkent az 1991/1995 időszak átlaga és 2002 között az EU Bizottság adatai szerint $^{13}$. Igaz, ugyanezen idő alatt az Egyesült Államok hasonló részesedése 15.1-röl 12.1, Japáné pedig 12.2-ről 8.2 százalékra esett vissza, tehát az EU a statisztikák szerint elsősorban a távol-keleti országokkal, különösen Kínával szemben vesztett pozíciókat. Csakhogy igazi versenytársai továbbra is a fejlett országok, a kínai export felfutásában is megmutatkozó világexport-növekedés fö tényezői pedig most is az amerikai és a japán bázisú transznacionális vállalatok (például a gyógyszer-, az elektronikai vagy az autóiparban) ${ }^{14}$.

A csúcstechnikai termékek világexportjában 1995 után erősödtek az amerikai pozíciók, ez pedig részben az EU versenyképesség-romlásával magyarázható. Az EU termelékenységi lemaradása is nőtt: az Unió évi átlagos termelékenység-növekedési üteme évi 1.9 százalékról (1991-95) 1.2 százalékra (1996-2001) esett vissza, miközben az Egyesült Államok két hasonló adata 1-1 százalékponttal magasabb volt. A relatív termelékenységi lemaradás néhány fó oka az EU-ban a következö ${ }^{15}$ :

- az információtechnológiai (ICT-) szektor lassú terjedése;

- az iparfejlődés hagyományos súlypontjai (közepes csúcstechnikai iparágak, érett tőkeintenzív iparágak) lassabban adják át helyüket a legfejlettebb iparágaknak a $\mathrm{K}+\mathrm{F}$ gyenge ösztönzése, illetve a merev munkaerö- és tőkepiac miatt;

- a kutatás-fejlesztési ráfordítások GDP-n belüli hányada a legtöbb EU-országban szignifikánsan alacsonyabb, mint az Egyesült Államokban;

- nehezebb a vállalatalapítás és az elbocsátás Európában, mint a tengerentúlon.

A közösségi gazdaságpolitika előtt tehát 2003-ban olyan kihívásokállnak a versenyképességi lemaradással kapcsolatban, amelyek kivédéséhez a határozott iparpolitikai cselekvés előbb-utóbb szükségessé válik ${ }^{16}$. Uniós dokumentumok erre fel is hívták a figyelmet, de egy 2002 júliusi szűkebb körü brüsszeli szakértői tanácskozáson Liikkanen főbiztos már meg is pedzette, hogy a 2000-ben meghirdetett lisszaboni program nem valósulhat meg közösségi iparpolitikai akciók nélkül.

A Lisszaboni Program (2000) célja: „az EU 2010-re a világ legdinamikusabb és legversenyképesebb tudásalapú gazdasága legyen, amely képes a fenntartható növekedésre több és jobb munkahellyel, valamint erösebb szociális kohézióval". A következő stratégiai lépés pedig a Göteborgi Program 2001-es meghirdetése volt. Ez a fenntartható fejlödés uniós stratégiája, amely együtt fogalmaz meg gazdasági, társadalmi és környezeti célokat, tehát jóval túlmegy a szűkebb értelemben vett gazdasági versenyképességi programon.

A 2000-es évek első felében tehát nemcsak a versenyképesség-javítási kényszer, hanem az uniós szintü gazdaságpolitikai gondolkodás megváltozása is arra készteti a magyar kormányt, hogy ismét fokozott iparpolitikai aktivitást mutasson, s ennek meg is teremtse a koncepcionális kereteit 2004-ben tehát kibontakozhat a magyar iparpolitika újabb, ötödik szakasza, most már válságkezelő elemek nélkül, elsősorban a K+F-támogatás, a regio-

\footnotetext{
${ }^{13}$ Az itt és a következő bekezdésben közölt adatok forrása: (Commission 2002).

${ }^{14}$ Erről részletesen lásd: (Scherer, 1996; UNCTAD, 2002).

${ }^{15}$ Forrás: (Commission, 2002) és a szerző saját brüsszeli információi.

${ }^{16}$ Erről a hazai szakirodalomban legújabban lásd: (Botos 2003). Az is tény, hogy több EU-országban volt aktív vállalkozáspolitika akkor is, amikor ilyen nem létezett azEU szintjén (Török 2002b).
} 
nális iparfejlesztés, valamint a kis- és középvállalati politika eszközeivel. Milyen stratégiai környezetben valósulhat meg ez az ötödik szakasz?

\section{A magyar iparfejlődés középtávú veszélyforrásai}

A következő gyengeségek, illetve veszélyek gátolhatják a magyar iparfejlődés kedvező pályán maradását 2003 után:

- A korszerű ipari kapacitások nagy része továbbra is multinacionális nagyvállalatok ellenőrzése alatt áll. Az IBM székesfehérvári merevlemez-gyárának bezárása jelzi, hogy akár nagy költségekkel létrehozott, a magyar gazdaságban látszólag mély gyökeret vert kapacitásokkal sem számolhat hosszabb távon a magyar gazdaságpolitika. Az IBM-eset értékeléséhez azonban hozzá tartozik, hogy ott egy nagyon rövid életciklusú, s egy igen konjunktúra-érzékeny iparág számára elóállított termék magyarországi gyártását fejezte be az amerikai nagyvállalat. $\mathrm{Az}$ autóiparban valószínűleg sokkal kevésbé fenyegetnek hasonló veszélyek;

- Az utóbbi megállapítás fel is idéz egy következö veszélyforrást: a magyar ipar jelenlegi struktúrájában jelentős dualitás jelei látszanak általában, és külön a külföldi befektetők jelenlétét illetően is. Egyes iparágakban - kivált a gépkocsi- és az elektronikai iparban - a világ vezető multinacionális cégei közül több is jelen van Magyarországon, mégpedig anemzetköziélvonalat megtestesítőtechnológiákkal. Több más iparágban - így a háztartási gépek gyártásában, a gyógyszeriparban, a cement-, a papír- vagy a söriparban - ugyancsak meghatározó a külföldi működő tőke jelenléte, ez azonban csak egyes cégeknél biztosítja a közvetlen technológiai kapcsolatot a világ élvonalával ${ }^{17}$. Nem tehát általában a külföldi tőke iparági koncentrációja, hanem a nemzetközileg legmagasabb müszaki színvonalat képviselő külföldi cégek iparági koncentrációja tekinthető szokatlanul magasnak a magyar iparban. Ez annyit jelent, hogy egy esetleges nemzetközi gépkocsi- és/vagy elektronikai ipari visszaesés az egész magyar ipar termelési és exportteljesítményét nagyban visszavetheti;

- A magyar iparcikk-export viszonylati függösége ugyancsak nagy. 2001-ben a magyar összkivitel 36 százaléka Németországba, csaknem fele pedig a német nyelvủ országokba (még Ausztriába és Svájcba) irányult ${ }^{18}$. A magyar gazdaság igen erősen függ a német gazdaság, illetve az egymással egyébként igen erősen öszszefonódott német és osztrák gazdaság konjunkturális helyzetétől. Ugyanabban az évben a teljes magyar kivitel 74 százalékát az EU 15 tagállama vette fel, ami a legtöbb uniós tagországgal összehasonlítva is kiugróan magas arány. Még sokkal nagyobb a magyar ipar jövője szempontjából stratégiai jelentőségü gépexport viszonylati koncentrációja: ott 2001-ben 84 százalékos volt az EU-piac és 91 százalékos a fejlett országok aránya. Ez azt is mutatja, hogy a magyar gépipar jelentős

${ }^{17}$ Közvetve megerősíti ezt Barta Györgyi adata: élesen elválnak egymástól a feldolgozóiparon belül a technológiaigényes és az egyéb ágazatok a gépállomány korszerüsége szempontjából. 1998-ban az innovatív gépiparban a vállalatok 27 százalékában a gépállomány több mint 60 százaléka volt korszerü, vagy csúcstechnikát képviselo" gép és berendezés, a hagyományos gépiparban viszont csak a vállalatok 9 százalékánál lehetett kimutatni hasonló arányt (Barta, 2002. 217.).

${ }^{18}$ Ennek részletes elemzését lásd: (Köves, 2003b). 
részben elveszítette 1990 előtti önálló piacait nemcsak a volt KGST-országokban, hanem a harmadik világban is. Az ágazat jelenlegi exportjának igen számottevő része ugyanis a multinacionális vállalati hálózatokon belüli szállításokból áll. 2001-ben a magyar összexport mintegy 58 százaléka gépipari termék volt, és ebből az 58 százalékból az Audi, az IBM, a Philips, a Flextronics, a Nokia, az Opel, a Suzuki és a Samsung magyarországi érdekeltsége együtt mintegy 2/3-nyi részt, a magyar összexport csaknem 40 százalékát szállította külföldre.

- A magyar ipari munkaerö szakképzettsége elmaradni látszik a külföldi befektetök igényeitöl. A megfelelő minőségü munkaerő-állományú nyugat-dunántúli és közép-magyarországi ipari telephelyeken általában már nem találni megfelelő minőségü új munkaerőt. A rossz közlekedés miatt a déli és a keleti régiókba nem szívesen települ a külföldi tőke, több példa volt azonban arra is, hogy azok a telephelyek a minőségi munkaerő hiányával küzdenek ${ }^{19}$. Bírálatok érik a külföldi befektetők részéről a magyar szakképzési és oktatási rendszert azért, mert nem törekszik eléggé a gazdaság gyakorlati igényeinek a kielégítésére ${ }^{20}$.

- A hazai kutatás-fejlesztés közvetlen ipari versenyképesség teremtő hatásai a magyar iparban alig erösödtek egy évtized alatt, és ez is elsősorban egyes multinacionális vállalatok magyar állami támogatással létrejött magyarországi kutatóközpontjainak köszönhető. Hiányoznak a megfelelö ösztönzők arra, hogy a magyarországi iparvállalatok belföldikutatóhelyeknek adjanak K+F megbízásokat. A kutatás-fejlesztés finanszírozása általában, és különösen az iparban elmarad a szükségestől nemcsak mértékében, hanem szerkezetében is. A GDP-ből K+F-re költött hányadot jelző GERD-mutató a kilencvenes évek második felében végig jóval 1 százalék alatt volt, de némi növekedése sem javította e kiadások szerkezetét ${ }^{21}$. Míg a fejlett országokban általánosnak tekinthető, hogy a GERD körülbelül 2/3-át az úgynevezett BERD (Business Expenditure on Research and Development, azaz az üzleti szféra K+F kiadásai) teszi ki, addig Magyarországon ez az arány 1995 után végig 35 és 40 százalék között mozgott. Az történt tehát, hogy az állam K+F kiadásainak növekedése nem húzta maga után a vállalkozások K+F megrendeléseit, valószínüleg a szükséges gazdaságpolitikai ösztönzők hiányában.

A fenti veszélyforrások arra utalnak, hogy a magyar ipar fejlödése 2003 és 2010 között várhatóan kevésbé lesz dinamikus, mint 1994-1995 után, ez azonban még nem jelenti azt, hogy ipari válság közeledik. Mindössze olyan visszafogottabb fejlődési szakaszt jelez, amelyben új iparfejlődési hajtóerőket kell feltárni és kihasználni ahhoz, hogy folytatódjék a magyar ipar eddig általában elismerésre méltó felzárkózása nyugat-európai versenytársaihoz.

19 1999-ben a General Electric a mintegy 10 ezres munkanélküliség sújtotta Ózd városában nyitott új üzemet. Helyi információk szerint a cég csak igen nehezen tudta feltölteni a telephely 1000 fös kezdő létszámát.

${ }^{20}$ A Magyar EU Bővitési Üzleti Tanács például 2003-ban javasolta a technikumi jellegü középiskolai képzés viszszaállítását, a kétszintü felsősoktatási rendszer gyakorlati követelményeknek megfelelő bevezetését úgy, hogy az erős egyetemi alapképzés ne gyengüljön a BSc szintü oktatás bevezetésével (HEBC 2003, 48.).

${ }^{21}$ Lásd: (Török 2002a). 


\section{Irodalom}

Barta, Györgyi (2002): A magyar ipar területi folyamatai. Dialóg Campus Kiadó, Budapest-Pécs. 272.

Biesbrouck, W. - Jackson, M. (1995): Markets and business competition: the institutional and economicframework. Megjelent: Jackson, M. - Biesbrouck, W. (szerk.): Marketization, Restructuring and Competition in Transition Industries of Central and Eastern Europe, 2. fej., 31-92. o. LICOS Studies on the Transitions in Central and Eastern Europe: Vol.3. LICOS Katholieke Universiteit Leuven - Avebury.

Botos, Balázs (1996): Az Európai Unió és Magyarország iparpolitikája: közös és eltérő vonások. Külgazdaság, Vol. XL., 1996/9. 34-41.

Botos, Balázs (2003): A bővülő Európa iparpolitikája. Fejlesztés és Finanszírozás 2003/3. Brada, Josef C. - Singh, Inderjit - Török Ádám (1994): Firms Afloat and Firms Adrift. Hungarian Industry and the Economic Transition. M. E. Sharpe, Armonk, New York. Commission (2002): Industrial Policy in an Enlarged Europe. European Commission, Brussels, COM (2002) 714 final.

Hamar, Judit (2001): A külföldi és a hazai tökével müködö vállalatok szerepe a magyar iparban. Külgazdaság, XLV. évf. 2001. április.

HEBC (Hungarian EU Enlargement Business Council, 2003): Célegyenesben. Magyarország sikeres integrációja. A Magyar EU Bővítési Üzleti Tanács ajánlásai. HEBC, Budapest, 78.

IKM (1993): A kormány középtávú iparpolitikája. Ipari Szemle. Vol. 13., 1993/1. 4-8.1.

IKM (1995): Középtávú iparpolitika az iparversenyképességének növeléséért. Kézirat. IKM, Budapest, 1995. december. 102 + ábrák és 2 függelék.

IKM (1995): Középtávú iparpolitika az ipar versenyképességének növeléséért. 2. függelék: Ágazati jövőképek (118 p.).Kézirat. IKM, Budapest, 1995. december.

Klodt, Henning (1992): Europäische Industriepolitik nach Maastricht. Die Weltwirtschaft, Heft 3, 1992. 263-273.1.

Köves, András (2003a): A KGST-kereskedelemtöl az EU-csatlakozásig. A kereskedelmi reorientáció néhány föbb kérdése a rendszerváltó országokban, különös tekintettel Magyarországra, I. rész. Kontinuitás és diszkontinuitás a külkereskedelmi kapcsolatokban. Közgazdasági Szemle, L. évfolyam, 2003. július-augusztus. 635-653.

Köves, András (2003b): A KGST-kereskedelemtöl az EU-csatlakozásig. A kereskedelmi reorientáció néhány fóbb kérdése a rendszerváltó országokban, különös tekintettel Magyarországra, II. rész. Reorientáció után, a tagság küszöbén. Közgazdasági Szemle, L. évfolyam, 2003. szeptember. 765-778.

KSH (1991): Az ipar és az épitöipar 1990. évi tevékenysége. Központi Statisztikai Hivatal, Budapest.

KSH (1992): Az ipar és az építőipar 1991. évi tevékenysége. Központi Statisztikai Hivatal, Budapest.

KSH (1993): Az ipar és az épitőipar 1992. évi tevékenysége. Központi Statisztikai Hivatal, Budapest.

KSH (1994): Az ipar és az épitöipar 1993. évi tevékenysége. Központi Statisztikai Hivatal, Budapest. 
KSH (1995): Az ipar és az épitöipar 1994. évi tevékenysége. Központi Statisztikai Hivatal, Budapest.

KSH (1997): Az ipar és az épitöipar 1996. évi tevékenysége. Központi Statisztikai Hivatal, Budapest.

KSH (1998): Az ipar és az építőipar 1997. évi tevékenysége. Központi Statisztikai Hivatal, Budapest.

KSH (1999): Az ipar és az épitőipar 1998. évi tevékenysége. Központi Statisztikai Hivatal, Budapest.

KSH (2000): Az ipar és az építőipar 1999. évi tevékenysége. Központi Statisztikai Hivatal, Budapest.

KSH (2001): Az ipar és az épitöipar 2000. évi tevékenysége. Központi Statisztikai Hivatal, Budapest.

KSH (2002): Az ipar és az építöipar 2001. évi tevékenysége. Központi Statisztikai Hivatal, Budapest.

KSH (2002a): Magyarország 1990-2001. Központi Statisztikai Hivatal, Budapest. 183.

KSH (2003): Az ipar és az épitőipar 2001. évi tevékenysége. Központi Statisztikai Hivatal, Budapest.

Lengyel, Imre (2002): The Competitiveness of Hungarian Regions. In: Varga, Attila Szerb, László (eds.): Innovation, Entrepreneurship, Regions and Economic Development. International Experiences and Hungarian Challenges. University of Pécs, 2002. 235-246. Nyitrai, Vera (2000/2001): Productivity Comparison. Acta Oeconomica Vol. 51, Number 4. 541-560.

Román, Zoltán (2003a): A lisszaboni stratégiai célok és a kis- és középvállalatok a jelölt országokban. Közgazdasági Szemle, L. évf., 2003. július-augusztus.

Román, Zoltán (2003b): A termelékenység növekedésének forrásai a magyar gazdaságban. Fejlesztés és Finanszírozás 2003/3.

Scherer, F.M. (1996): Industry Structure, Strategy and Public Policy. HarperCollins CollegePublishers, New York, 1996. 436.

Somai, Miklós (1993): Autóiparés autópiac Magyarországon. Ipargazdasági Szemle 1993/22. 61-86.

Soós, Károly Attila (2002): Az átmeneti gazdaságok EU-exportja nemzetközi összehasonlításban. Közgazdasági Szemle 49. évf., 2002. 12. 1063-1080.

Stephan, Johannes (2002): The Productivity Gap between East and West Europe: What Role for Sectoral Structures during Integration? Acta Oeconomica, Vol. 52, Nr. 3. (2002) 289307.

Török, Ádám (1995): Magyar iparfejlödés középtávon - jövőkép és forgatókönyvek. Közgazdasági Szemle, 1995. 3. 901-925.

Török, Ádám (1997): A magyar iparfejlődés, a társulási szerződés és az Európai Unió fehér könyve. Európa Fórum, 1997. 1. 45-65.

Török, Ádám (1999): Verseny a versenyképességért? Mikroszféra-kezelési politikák az Európai Unóban és Magyarországon. Integrációs Stratégiai Munkacsoport, 1999. 300.

Török, Ádám (2001a): A gazdasági modernizáció stratégiája Finnországban I. Vezetéstudomány, Vol. XXXII. 2001/7-8. 58-73.

Török, Ádám (2001b): A gazdasági modernizáció stratégiája Finnországban II. Vezetéstudomány, Vol. XXXII. 2001/9. 31-38. 
Török, Ádám (2002a): Hungarian Science and Technology in the Top Twenty? In: Varga, Attila - Szerb, László (eds.): Innovation, Entrepreneurship, Regions and Economic Development. International Experiences and Hungarian Challenges. University of Pécs, 2002. 11-26.

Török, Ádám (2002b): A hazai (nagy) vállalkozások helyzete és stratégiája - nemzetközi tapasztalatok. Vezetéstudomány, XXXIII. évfolyam 2002. különszám. 3-13.

Török, Attila (2001): Olaszország - igazodás külső kényszer hatására. Tanulmány az olasz vállalattámogatás rendszeréről a hazai (nagy) vállalkozások helyzetét értékelö és stratégiát megalapozó kutatás nemzetközi blokkja számára. Világgazdasági Kutatásokért Alapítvány, Budapest, 2001. 34.

UNCTAD (2002): World Investment Report 2002. Transnational Corporations and Export Competitiveness. United Nations, New York and Geneva, 2002. 350. 